\title{
Large contribution of organics to condensational growth and formation of cloud condensation nuclei (CCN) in the remote marine boundary layer
}

\author{
Guangjie Zheng ${ }^{1,2}$, Chongai Kuang ${ }^{2}$, Janek Uin ${ }^{2}$, Thomas Watson ${ }^{2}$, and Jian Wang ${ }^{1,2}$ \\ ${ }^{1}$ Center for Aerosol Science and Engineering, Department of Energy, Environmental and Chemical Engineering, \\ Washington University in St. Louis, St. Louis, Missouri, USA \\ ${ }^{2}$ Environmental and Climate Science Department, Brookhaven National Laboratory, Upton, New York, USA
}

Correspondence: Jian Wang (jian@wustl.edu)

Received: 23 June 2020 - Discussion started: 3 July 2020

Revised: 31 August 2020 - Accepted: 8 September 2020 - Published: 1 November 2020

\begin{abstract}
Marine low clouds strongly influence global climate, and their radiative effects are particularly susceptible to the concentration of cloud condensation nuclei $(\mathrm{CCN})$. One major source of $\mathrm{CCN}$ is the condensational growth of pre$\mathrm{CCN}$ particles, and sulfate has long been considered the major condensing species in the remote marine boundary layer. While some studies have suggested that secondary organic species can contribute to particle growth, its importance remains unclear. Here we present the first long-term observational evidence that organics play an important role in particle growth over remote oceans. To the contrary of traditional thinking, sulfate dominated condensational growth for only a small $(\sim 18 \%)$ fraction of the 62 observed growth events, even fewer than the organic-dominated events $(24 \%)$. During most $(58 \%)$ growth events, the major condensing species included both organics and sulfate. Potential precursors of the secondary organics are volatile organic compounds from ocean biological activities and those produced by the air-sea interfacial oxidation. Our results indicate that the condensation of secondary organics contributes strongly to the growth of pre-CCN particles and thereby the $\mathrm{CCN}$ population over remote oceans.
\end{abstract}

\section{Introduction}

Marine low clouds play an important role in the global climate system (Wood, 2012), and their properties and radiative effects are very sensitive to the concentration of cloud con- densation nuclei (CCN) (Carslaw et al., 2013; Rosenfeld et al., 2019). Condensational growth of pre-CCN particles (i.e., particles that are too small to form cloud droplets) (Hoppel et al., 1990; Pierce and Adams, 2006) is one major source of $\mathrm{CCN}$ in the remote marine boundary layer (MBL) (Pierce and Adams, 2006; Yu and Luo, 2009; Sanchez et al., 2018) and is likely the dominant one in late spring to fall (Zheng et al., 2018). Over open ocean, dimethyl sulfide (DMS) is the dominant biogenic volatile organic compound (VOC). The major oxidation products of DMS are sulfur dioxide $\left(\mathrm{SO}_{2}\right)$ and methanesulfonic acid (MSA) (Andreae et al., 1985). Further oxidation of $\mathrm{SO}_{2}$ produces sulfuric acid $\left(\mathrm{H}_{2} \mathrm{SO}_{4}\right)$, which readily condenses onto existing particles and participates in the formation of new particles (Kulmala et al., 2000). It has long been recognized that sulfate produced from DMS oxidation is a major species for particle condensational growth in the remote marine environment (Charlson et al., 1987; Raes and Van Dingenen, 1992; Pandis et al., 1994; O'Dowd et al., 1999; Sanchez et al., 2018). Earlier studies (Willis et al., 2016; Kerminen and Wexler, 1997; Karl et al., 2011) suggest that MSA may also contribute to the growth of pre-CCN particles and thus the formation of CCN. However, the effect of MSA condensation on marine $\mathrm{CCN}$ concentration remains unclear. Model-simulated effects range from negligible (e.g., a few percent) to significant $(\sim 20 \%)$, depending on the assumption of MSA volatility and the geographic location (Hodshire et al., 2019).

It has been suggested that in the remote MBL, secondary organics produced from two types of non-DMS VOCs can 
contribute substantially to particle condensational growth. The first type of VOCs, including isoprene, monoterpenes, and aliphatic amines (Facchini et al., 2008; Dall'Osto et al., 2012; Willis et al., 2017), is related to ocean biological activities, and secondary organic aerosol (SOA) produced from these VOCs are positively correlated with MSA (Dall'Osto et al., 2012; Willis et al., 2016, 2017; Kim et al., 2017). While the mixing ratios of isoprene and monoterpenes are typically quite low over open ocean (Hu et al., 2013) due to their weak emissions, on rare occasions, elevated monoterpene mixing ratios of up to $\sim 100 \mathrm{ppt}$ were observed (Kim et al., 2017), possibly due to enhanced microorganism growth as a result of nutrient replenishment (Kim et al., 2017). The second type of VOCs is produced by the oxidation reactions at the air-sea interface, especially when the sea surface microlayer is enriched in organic surfactants (Mungall et al., 2017; Brüggemann et al., 2018). These water-soluble organics can come from phytoplankton but can also be from other sources, including other autotrophs and atmospheric depositions (Wurl et al., 2011). Therefore, this type of oceanic VOCs and thus SOA formed may not correlate with MSA (Wurl et al., 2011; Mungall et al., 2017; Brüggemann et al., 2018).

At present, the contribution of secondary organics to the growth of pre-CCN particles in the MBL and the seasonal variation of this contribution remain unclear, largely due to the scarcity of pre-CCN particle composition measurements. Previous studies of pre-CCN growth in the MBL were typically within relatively short time periods (i.e., about 1 month) (Dall'Osto et al., 2012; Willis et al., 2016, 2017; Kim et al., 2017; Mungall et al., 2017; Vaattovaara et al., 2006; Modini et al., 2009; Bzdek et al., 2014; Lawler et al., 2014; Swan et al., 2016) and were often conducted in coastal regions (Vaattovaara et al., 2006; Modini et al., 2009; Dall'Osto et al., 2012; Bzdek et al., 2014; Lawler et al., 2014; Swan et al., 2016) with substantial influences from continental emissions. Here we present the first long-term observational constraint on the importance of secondary organics to the growth of pre-CCN particles in the remote MBL. Hygroscopicity of size-classified particles was characterized over a period of 14 months in the Eastern North Atlantic. By taking advantage of the contrasting hygroscopicity values of sulfate, MSA, and other secondary organic species, we constrain and identify the major species that are responsible for the growth of pre$\mathrm{CCN}$ particles. Our results show that the organics represent an important or even dominant condensing species during $\sim 80 \%$ of growth events.

\section{Measurements and datasets}

The Eastern North Atlantic (ENA) atmospheric observatory was established by the Atmospheric Radiation Measurement (ARM) Climate Research Facility (https://www. arm.gov/capabilities/observatories/ena, last access: 15 October 2020) in October 2013. This remote oceanic site, lo- cated on Graciosa Island, the Azores, Portugal $\left(39^{\circ} 5^{\prime} 30^{\prime \prime} \mathrm{N}\right.$, $28^{\circ} 1^{\prime} 32^{\prime \prime} \mathrm{W} ; 30.48 \mathrm{~m}$ above mean sea level) (Mather and Voyles, 2013), straddles the boundary between the subtropics and midlatitudes in the Eastern North Atlantic. The ENA is a region of persistent but diverse marine low clouds, the albedo and precipitation of which are highly susceptible to perturbations of aerosol properties (Wood, 2012; Carslaw et al., 2013). Air masses arriving at this site can originate from North America, northern Europe, the Arctic, and the Atlantic (Wood et al., 2015; Wang et al., 2016; Zheng et al., 2018). Routine measurements at the ENA site include meteorological parameters, trace gas mixing ratios, and aerosol and cloud properties (Zheng et al., 2018). The relevant routine measurements used in this study are summarized in Sect. 2.3.

From June 2017 to August 2018, the Aerosol and Cloud Experiments in the Eastern North Atlantic (ACE-ENA) campaign (Wang et al., 2016) was conducted in the Azores to investigate the aerosol-cloud interactions in the remote marine boundary layer (MBL). As a key part of this campaign, additional aerosol measurements were carried out at the ENA site, including aerosol size distribution and size-resolved CCN activated fractions (Mei et al., 2013b; Thalman et al., 2017). The instruments and calibration procedures are detailed elsewhere (Zheng et al., 2020) and are briefly described below. The data from these measurements are available at https://www.arm.gov/research/campaigns/aaf2017ace-ena (last access: 15 October 2020).

\subsection{Size distribution measurements and mode fittings}

Aerosol size distribution was measured by a scanning mobility particle sizer (SMPS; Model 3938, TSI Incorporated, Shoreview, MN, USA). Dry ( $\mathrm{RH}<25 \%$ ) aerosol number size distribution ranging from 10 to $470 \mathrm{~nm}$ in particle diameter was measured every $8 \mathrm{~min}$. In addition, a condensation particle counter (CPC; Model 3772, TSI Incorporated, Shoreview, MN, USA) was operated side-by-side to measure the total aerosol number concentrations $(\mathrm{CN})$ concurrently. The measured aerosol number size distributions are fitted as a sum of up to three lognormal modes. Based on the fitted mode geometric mean diameters $\left(D_{\mathrm{p}, \mathrm{n}}\right)$, the fitted modes are classified as the nucleation mode $\left(D_{\mathrm{p}, \mathrm{n}}<20 \mathrm{~nm}\right)$, the Aitken mode $\left(20<D_{\mathrm{p}, \mathrm{n}}<\sim 80 \mathrm{~nm}\right)$, the accumulation mode $\left(\sim 80<D_{\mathrm{p}, \mathrm{n}}<\sim 300 \mathrm{~nm}\right)$, and the sea spray aerosol mode $\left(D_{\mathrm{p}, \mathrm{n}}>\sim 300 \mathrm{~nm}\right)$ (Quinn et al., 2017; Zheng et al., 2018).

\subsection{Size-resolved CCN activated fraction measurements}

The size-resolved CCN measurement system (SCCN) consists of a differential mobility analyzer (DMA; TSI Inc., Model 3081) coupled to a CPC (TSI Inc., Model 3010) and a cloud condensation nuclei counter (CCNC; Droplet Measurement Technologies, Boulder, CO) (Frank et al., 2006; Moore et al., 2010; Petters et al., 2007; Mei et al., 2013a). 
This system measures the activated fraction (i.e., the fraction of particles that activate and form cloud droplets) of sizeclassified particles as a function of supersaturation (Thalman et al., 2017). During the ACE-ENA campaign, the DMA stepped through six dry particle diameters $\left(D_{\mathrm{p}, \mathrm{SCCN}}\right)$ of 40 , $50,75,100,125$, and $150 \mathrm{~nm}$. At each $D_{\mathrm{p}, \mathrm{SCCN}}$, the supersaturation level inside the CCNC was varied by changing the flow rate and/or temperature gradient $T$. The corresponding supersaturation levels, ranging from $0.07 \%$ to $1.34 \%$ at $298 \mathrm{~K}$, were calibrated using ammonium sulfate particles following established procedures (Lance et al., 2013; Mei et al., 2013a; Thalman et al., 2017). An entire measurement cycle through the six particle diameters took between 1 and $2 \mathrm{~h}$, depending on particle number concentration. Temperature dependence of CCNC supersaturation (Rose et al., 2008; Thalman et al., 2017) and the effect of multi-charged particles (Thalman et al., 2017) are taken into consideration. The particle hygroscopicity parameter under supersaturated conditions, $\kappa_{\mathrm{CCN}}$ (Petters and Kreidenweis, 2007), is derived from the activated fraction spectrum and the corresponding particle diameter (Lance et al., 2013; Mei et al., 2013a; Thalman et al., 2017).

\subsection{Other relevant datasets used in this study}

Routine measurements at the ENA site used in this study include the non-refractory submicron aerosol (NR-PM 1$)$ composition (organics, sulfate, nitrate, ammonium, and chloride) characterized by an aerosol chemical speciation monitor (ACSM; Aerodyne Research, Inc., Billerica, MA, USA) (Watson, 2017) and particle hygroscopic growth measured by a humidified tandem differential mobility analyzer (HTDMA; Brechtel Manufacturing Inc., CA, USA) (Uin, 2016). The HTDMA measures aerosol hygroscopic growth factor under $\sim 80 \% \mathrm{RH}$ at five particle diameters $(50,100,150$, 200 and $250 \mathrm{~nm}$ ), from which the aerosol hygroscopicity under subsaturated conditions $\left(\kappa_{\mathrm{GF}}\right)$ is derived (Petters and Kreidenweis, 2007).

Gas-phase $\mathrm{SO}_{2}$ and MSA concentrations are from the Modern-Era Retrospective Analysis for Research and Applications, version 2 (MERRA-2) reanalysis data (Gelaro et al., 2017), at the grid corresponding to the ENA site.

\section{Derivation of the hygroscopicity parameter of condensing species}

Continuous growth of Aitken-mode particles is identified from the aerosol size distribution time series. As a result of the condensational growth, aerosol chemical compositions and thus the hygroscopicity of Aitken-mode particles are expected to evolve with time during the growth events. As potential condensing species (Table 1) have contrasting hygroscopicity parameters, the variation of hygroscopicity param- eter during the growth events can therefore be used to infer the major condensing species.

\subsection{Matching aerosol size modes with the hygroscopicity measurements}

Here we detail the procedure to correlate the aerosol size distribution with the SCCN measurement. The same procedure is also applied to correlate the aerosol size distribution with the HTDMA measurements. The CCN activated fraction spectrum was measured at six fixed sizes $\left(D_{\mathrm{p}, \mathrm{SCCN}}\right)$. As the size of Aitken-mode particles evolves continuously during the growth events, we first determine if the hygroscopicity of the growing Aitken mode can be captured by the measurement at one of the six $D_{\mathrm{p}, \mathrm{SCCN}}$ using the following two criteria. The first criterion is that $D_{\mathrm{p}, \mathrm{SCCN}}$ (e.g., 40, 50, or $75 \mathrm{~nm})$ is within 1 geometric standard deviation $(\sigma)$ of the Aitken-mode diameter; i.e., $D_{\mathrm{p}, \mathrm{n}} \sigma^{-1}<D_{\mathrm{p}, \mathrm{SCCN}}<D_{\mathrm{p}, \mathrm{n}} \sigma$ (Fig. 1a). For example, at time $t_{0}, D_{\mathrm{p}}, \mathrm{SCCN}(40 \mathrm{~nm})$ is within $1 \sigma$ range of the Aitken-mode diameter (i.e., dark blue shaded area in Fig. 1a), and the $\kappa_{\mathrm{CCN}}$ value measured at $40 \mathrm{~nm}$ is considered representative of the Aitken mode (solid blue curve in Fig. 1a). In contrast, at a later time $t_{1}$, the Aitken mode grew to larger sizes (dashed blue curve in Fig. 1a), and $40 \mathrm{~nm}$ became smaller than $D_{\mathrm{p}, \mathrm{n}} \sigma^{-1}$ (light blue shaded area in Fig. 1a). Therefore, $\kappa_{\mathrm{CCN}}$ measured at $40 \mathrm{~nm}$ no longer represents the hygroscopicity of the Aitken mode at $t_{1}$. The second criterion is that particle concentration at $D_{\mathrm{p}, \mathrm{SCCN}}$ is dominated by the Aitken mode only (Fig. 1b); i.e., a total of over $95 \%$ of the particles at the measured $D_{\mathrm{p}, \mathrm{SCCN}}$ is contributed by the Aitken mode. The Aitken mode (blue curve) and accumulation mode (red curve) contribute to the number size distribution at $D_{\mathrm{p}, \mathrm{SCCN}}$ (dashed black line, Fig. 1b). Although $D_{\mathrm{p}, \mathrm{SCCN}}$ is within $1 \sigma$ of the Aitken-mode diameter, the contribution of the Aitken mode is less than $95 \%$ at this size (orange curve in Fig. 1b). Therefore, measurement at $D_{\mathrm{p}, \text { SCCN }}$ is not deemed as being representative of the Aitken mode due to the substantial contribution from accumulationmode particles. Only data points that meet both criteria are selected, as illustrated in Fig. 1c. Figure 2 a gives an example of the time series of Aitken-mode diameter and paired $\kappa_{\mathrm{CCN}}$ value during a growth event.

\subsection{Derivation of the hygroscopicity of condensed species $\left(\kappa_{c}\right)$ during growth events}

The derivation is applied to condensational growth events when there are a sufficient number (more than six points) of $\kappa$ measurements that satisfy both criteria described in Sect. 3.1. For each condensational growth event selected (e.g., Fig. 2a), the average hygroscopicity parameter of condensing species, $\kappa_{\mathrm{c}}$, is derived based on the following three assumptions. Here, $\kappa$ represents either the hygroscopicity derived from SCCN (i.e., $\kappa_{\mathrm{CCN}}$ ) or HTDMA (i.e., $\kappa_{\mathrm{GF}}$ ) data. 

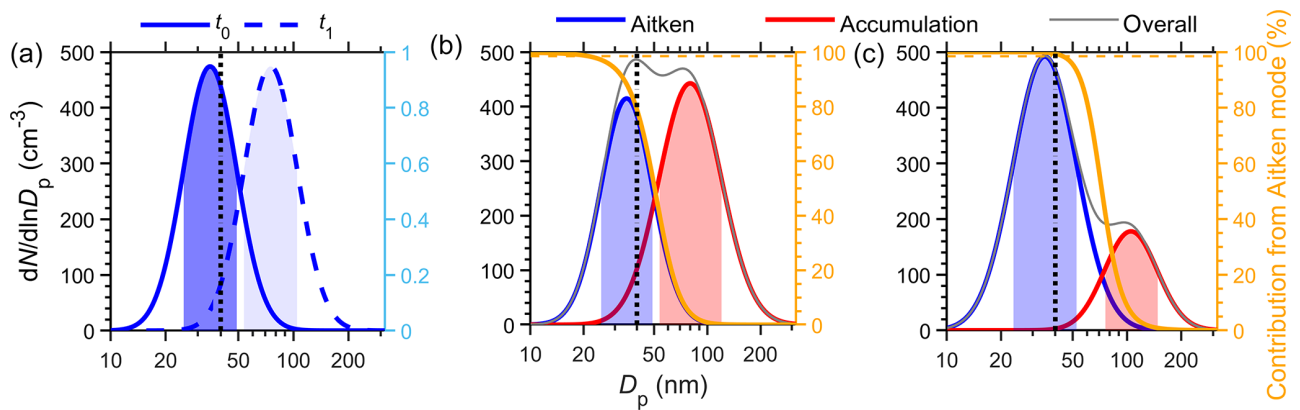

Figure 1. Matching aerosol Aitken mode with hygroscopicity measurements at fixed particle diameters. The dashed black lines indicate the selected particle size (i.e., $D_{\mathrm{p}}, \mathrm{SCCN}$ ) at which the hygroscopicity parameter $\kappa$ is derived. The shaded areas indicate the $1 \sigma$ range from the fitted lognormal mode diameter, $D_{\mathrm{p}, \mathrm{n}}$.

Table 1. Hygroscopicity parameter $\kappa$ of potential condensing species over remote oceans.

\begin{tabular}{llll}
\hline Compound & $\kappa_{\mathrm{GF}}$ & $\kappa_{\mathrm{CCN}}$ & Reference \\
\hline $\mathrm{H}_{2} \mathrm{SO}_{4}$ & 1.19 & 0.90 & Petters and Kreidenweis (2007) \\
$\mathrm{NH}_{4} \mathrm{HSO}_{4}$ & 1.0 & 0.9 & Schmale et al. (2018) \\
$\left(\mathrm{NH}_{4}\right)_{3} \mathrm{H}_{\left(\mathrm{SO}_{4}\right)_{2}}$ & 0.51 & 0.65 & Petters and Kreidenweis (2007) \\
$\left(\mathrm{NH}_{4}\right)_{2} \mathrm{SO}_{4}$ & 0.53 & 0.61 & Petters and Kreidenweis (2007) \\
$\mathrm{CH}_{3} \mathrm{SO}_{3} \mathrm{H} \quad(\mathrm{MSA})$ & 0.36 & $<0.44$ & Johnson et al. (2004) and Tang et al. (2019) \\
$\alpha$-pinene/O $/$ dark SOA & $0.022-0.037$ & 0.1 & Petters and Kreidenweis (2007) \\
$\beta$-pinene/O $/$ dark SOA & $0.009-0.022$ & 0.1 & Petters and Kreidenweis (2007) \\
\hline $\begin{array}{l}\text { SOA particles } \\
\text { generated via OH }\end{array}$ & $0-0.3(20 \%$ to & $0-0.3$ (generally & Chang et al. (2010) \\
radical oxidation & $50 \%$ lower than & below the line of & and Massoli et al. (2010) \\
\hline
\end{tabular}

The first assumption is that the change in particle volume (diameter) is due to the condensational growth only, namely

$V_{\mathrm{c}}=\Delta V=V_{1}-V_{0}=(\pi / 6) D_{\mathrm{p} 1}^{3}-(\pi / 6) D_{\mathrm{p} 0}^{3}$,

where $V$ is the particle volume and $D_{\mathrm{p}}$ is the particle diameter. Hereinafter we use $X_{1}$ and $X_{0}$ to denote the corresponding particle property $X$ after and before the condensational growth, respectively, and $X_{\mathrm{c}}$ refers to the property $X$ of the condensed species. The second assumption is that the aerosol $\kappa$ follows the volume-weighted mixing law (Petters and Kreidenweis, 2007):

$\kappa_{1}=\kappa_{0}\left(V_{0} / V_{1}\right)+\kappa_{\mathrm{c}}\left(V_{\mathrm{c}} / V_{1}\right)$.

The third assumption is that the growth rate is identical for particles of the same size, and thus the relative position of any given particle in the accumulative size distribution is maintained throughout the growth. Let $\mathrm{CDF}_{0}$ and $\mathrm{CDF}_{1}$ denote the particle cumulative size distributions before and after the particle growth, and $D_{\mathrm{p} 0}$ and $D_{\mathrm{p} 1}$ represent particle diameters before and after particle growth, respectively. The number of particles smaller than $D_{\mathrm{p} 1}$ following particle growth should be the same as the number of particles smaller than $D_{\mathrm{p} 0}$ prior to the growth event (Fig. 2b):

$\mathrm{CDF}_{1}\left(D_{\mathrm{p} 1}\right)=\mathrm{CDF}_{0}\left(D_{\mathrm{p} 0}\right)$
For each particle size (i.e., $\left.D_{\mathrm{p} 1}\right)$ measured during the growth events, the original particle size (i.e., $D_{\mathrm{p} 0}$ ) is derived from Eq. (3). The volume fraction of condensed species, $f_{\mathrm{V}}$, cond, is given by

$$
f_{\mathrm{V}, \text { cond }}=V_{\mathrm{c}} / V_{1}=1--V_{0} / V_{1}=1-\left(D_{\mathrm{p} 0} / D_{\mathrm{p} 1}\right)^{3} \text {. }
$$

By combining Eqs. (1)-(4), we have

$\kappa_{1}=\left(\kappa_{c-} \kappa_{0}\right) f_{\mathrm{V}, \text { cond }}+\kappa_{0}$.

Both $\kappa_{1}$ and $f_{\mathrm{V}}$, cond are from the measurements as described above. Therefore, $\kappa_{\mathrm{c}}$ and $\kappa_{0}$ can be derived from the linear fitting of $\kappa_{1}$ vs. $f_{\mathrm{V}}$, cond for each growth event (e.g., Fig. 2c), where $\kappa_{0}$ is the intercept and $\kappa_{\mathrm{c}}$ is the sum of slope and intercept. The method described here was applied to both SCCN and HTDMA measurements, and $\kappa_{\mathrm{c}}$ derived values are referred to as $\kappa_{\mathrm{c}, \mathrm{CCN}}$ and $\kappa_{\mathrm{c}, \mathrm{GF}}$ hereinafter, respectively.

\section{Constraining the major condensing species in the remote $\mathrm{MBL}$}

Figure 3 shows two examples of the identified growth events, with the dominant condensing species being sulfate and organics, respectively. While the measured $\kappa_{\mathrm{CCN}}$ values of the 

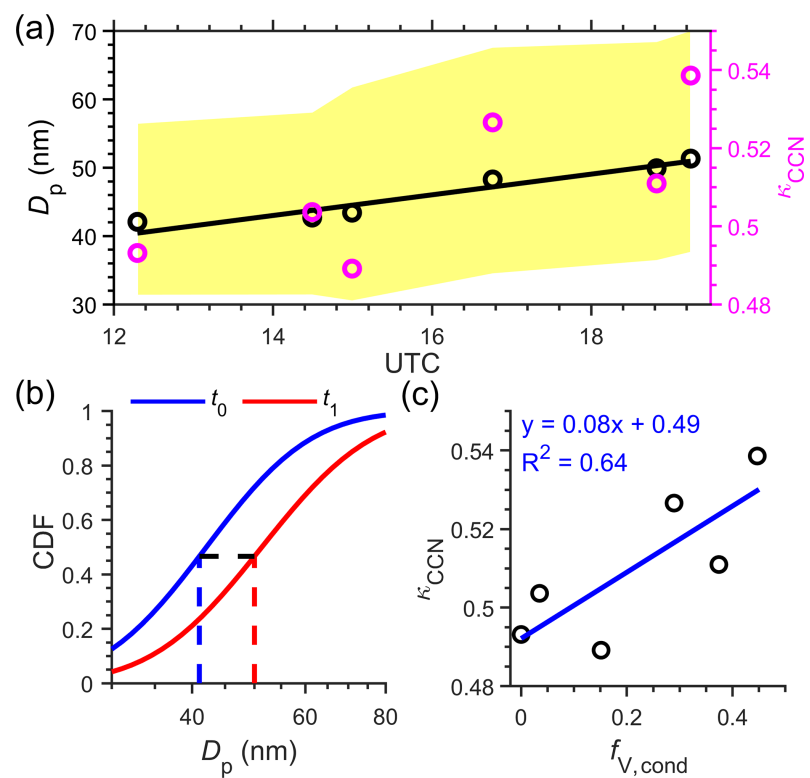

(c)

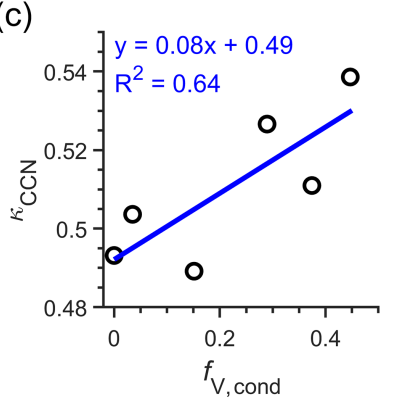

Figure 2. Derivation of $\kappa_{\mathrm{c}, \mathrm{CCN}}$ from size-resolved CCN measurement during an example condensational growth event. (a) Mode diameter and hygroscopicity $\kappa_{\mathrm{CCN}}$ of the growing Aitken mode. The black circles are the fitted mode diameter, $D_{\mathrm{p}, \mathrm{n}}$, and the shaded area indicates the $1 \sigma$ range of the fitted mode. The black line shows the increasing trend of $D_{\mathrm{p}, \mathrm{n}}$, which is used to identify growth events. (b) Derivation of the original particle diameter $\left(D_{\mathrm{p} 0}\right)$ at the beginning of the growth event from particle diameter measured after growth $\left(D_{\mathrm{p} 1}\right)$ using cumulative particle size distributions. (c) Derivation of $\kappa_{\mathrm{c}, \mathrm{CCN}}$ through linear fitting of $\kappa_{\mathrm{CCN}} \mathrm{vs}$. $f_{\mathrm{V}, \text { cond. }}$

Aitken-mode particles (i.e., pre-CCN particles that are below $\sim 80 \mathrm{~nm})$ are similar $(\sim 0.45)$ at the start of both events, the variations of $\kappa_{\mathrm{CCN}}$ with growing particle size show opposite trends. For the July case (Fig. 3a, b), $\kappa_{\mathrm{CCN}}$ increased with the volume fraction of condensed species ( $f_{\mathrm{V} \text {,cond }}$, Fig. $3 \mathrm{~b}$ ), indicating that the hygroscopicity of the condensed species, $\kappa_{\mathrm{c}, \mathrm{CCN}}$, exceeds that of the original particles. The derived $\kappa_{\mathrm{c}, \mathrm{CCN}}$ value is 0.7 , which is typical of sulfates (Table 1 ). In contrast, during the September growth event (Fig. 3c, d), $\kappa_{\mathrm{CCN}}$ decreased as the particles grew. The derived $\kappa_{\mathrm{c}, \mathrm{CCN}}$ value is $\sim 0.3$, indicating organics as the dominant condensing species. We note that $\kappa_{\mathrm{c}, \mathrm{CCN}}$ is derived from the volumeweighted mixing law (Petters and Kreidenweis, 2007) (i.e., ideal Zdanovskii-Stokes-Robinson (ZSR) mixing). Organic surfactants may facilitate $\mathrm{CCN}$ activation by lowering surface tension of growing droplets (Ovadnevaite et al., 2017). In scenarios when particles contain organic surfactants, particle hygroscopicity $\kappa_{\mathrm{CCN}}$ may be greater than the simple volume average of participating species. As a result, the derived $\kappa_{\mathrm{c}, \mathrm{CCN}}$ value based on the volume-weighted mixing law may be overestimated, therefore leading to an underestimation of the contribution of organics to the particle condensational growth.
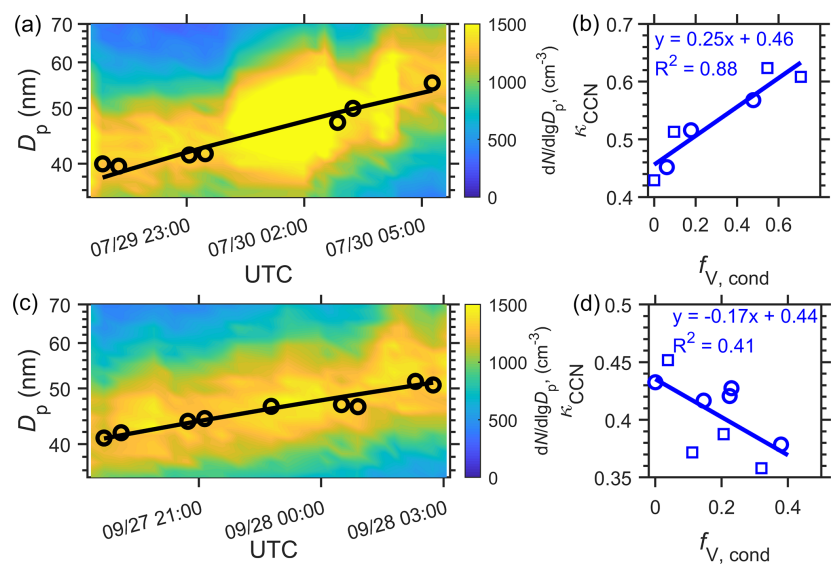

Figure 3. Examples of pre-CCN particle growth dominated by (a, b) acidic sulfates and (c, d) organics, respectively, as observed in 2017. (a) and (c) Examples of growth events identified from the time series of measured aerosol size distribution. The black circles indicate lognormal-fitted Aitken-mode diameter, and the black lines indicate the growth of the mode diameter (see Sect. 3). (b) and (d) Particle hygroscopicity $\kappa_{\mathrm{CCN}}$ as a function of the volume fraction of condensed species in the growing particles $\left(f_{\mathrm{V} \text {,cond }}\right)$. $f_{\mathrm{V} \text {,cond }}$ increases as particles grow by condensation. The value of $\kappa_{\mathrm{c}, \mathrm{CCN}}$ is derived from the variation of $\kappa_{\mathrm{CCN}}$ with $f_{\mathrm{V} \text {, cond }}$ (Sect. 3 ).

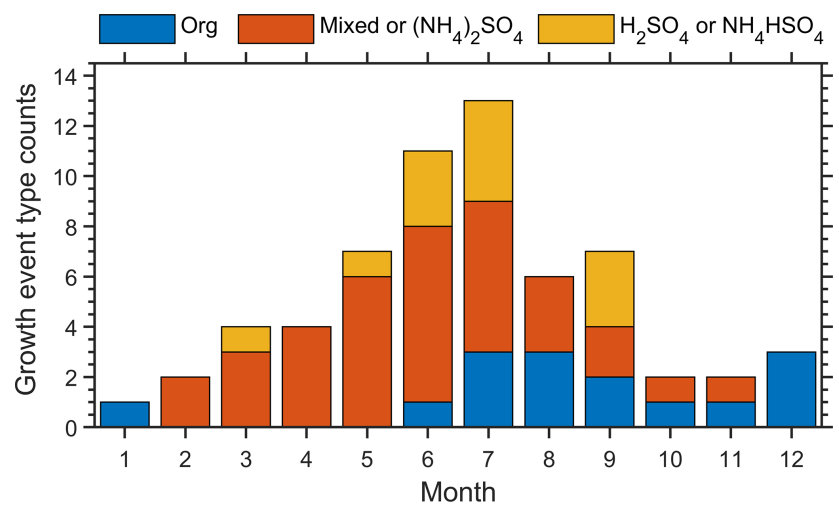

Figure 4. Monthly distribution of observed condensational growth events and the category of dominant condensing species during the ACE-ENA campaign.

A total of 62 growth events are identified during the 14month campaign (Fig. 4). These events are classified into three categories according to the derived $\kappa_{\mathrm{c}, \mathrm{CCN}}$ value (Table 1): (1) low hygroscopicity (i.e., $\kappa_{\mathrm{c}, \mathrm{CCN}}<0.45$ ), indicating organics as being the dominant condensing species, (2) high hygroscopicity (i.e., $\kappa_{\mathrm{c}, \mathrm{CCN}}>0.65$ ), with acidic sulfate (i.e., $\mathrm{H}_{2} \mathrm{SO}_{4}$ or $\mathrm{NH}_{4} \mathrm{HSO}_{4}$ ) dominating the particle condensational growth, and (3) intermediate hygroscopicity (i.e., $\left.0.45<\kappa_{\mathrm{c}, \mathrm{CCN}}<0.65\right)$, when $\left(\mathrm{NH}_{4}\right)_{2} \mathrm{SO}_{4}$ and/or mixtures of organics and acidic sulfate contribute to the particle growth. 


\section{Monthly distributions of the dominant condensing species}

The monthly distribution of the identified growth events and the dominant condensing species are shown in Fig. 4. Relatively more events were observed during the summer seasons due to favorable synoptic conditions. In summer, there is a stronger influence by the Azores High, while the influence from midlatitude cyclones and the corresponding wet scavenging are much weaker (Zheng et al., 2018). The distribution of the event categories shows that $\mathrm{NH}_{4} \mathrm{HSO}_{4} / \mathrm{H}_{2} \mathrm{SO}_{4}$ dominated the condensational growth during only $18 \%$ of the growth events. This is less than the events dominated by organics at $24 \%$. The majority $(58 \%)$ of the growth events exhibit intermediate $\kappa_{\mathrm{c}, \mathrm{CCN}}$ values, suggesting that $\left(\mathrm{NH}_{4}\right)_{2} \mathrm{SO}_{4}$ or a mixture of organics and sulfate is responsible for the particle condensational growth.

To further constrain the condensing species for the intermediate $\kappa_{\mathrm{c}, \mathrm{CCN}}$ category, we compare the $\kappa_{\mathrm{c}, \mathrm{CCN}}$ value with the hygroscopicity under subsaturated conditions $\left(\kappa_{\mathrm{c}, \mathrm{GF}}\right)$, which is derived from measured particle hygroscopic growth (Sect. 3). For $\left(\mathrm{NH}_{4}\right)_{2} \mathrm{SO}_{4}$, the difference between $\kappa_{\mathrm{c}, \mathrm{CCN}}$ and $\kappa_{\mathrm{c}, \mathrm{GF}}$ is relatively small (within $20 \%$ ) (Petters and Kreidenweis, 2007), while the difference is usually substantially larger (Wex et al., 2009; Rastak et al., 2017; Petters et al., 2009; Pajunoja et al., 2015; Ovadnevaite et al., 2011; Massoli et al., 2010) for organic species. The large difference has been attributed to the solution non-ideality (Petters et al., 2009), the formation of hydrogels (Ovadnevaite et al., 2011), and the solubility and phase states (Pajunoja et al., 2015; Rastak et al., 2017). One example of the intermediate $\kappa_{\mathrm{c}, \mathrm{CCN}}$ category is shown in Fig. S1 in the Supplement. For this case, the derived $\kappa_{\mathrm{c}, \mathrm{CCN}}$ and $\kappa_{\mathrm{c}, \mathrm{GF}}$ values are 0.59 and 0.45 , respectively (Fig. S1). The difference is close to the measurement uncertainty (i.e., $20 \%$ ), and therefore the major condensing species for this example is classified as $\left(\mathrm{NH}_{4}\right)_{2} \mathrm{SO}_{4}$.

Figure 5 compares the values of $\kappa_{\mathrm{c}, \mathrm{CCN}}$ and $\kappa_{\mathrm{c}, \mathrm{GF}}$ for all available events in the intermediate $\kappa_{\mathrm{c}, \mathrm{CCN}}$ category. For most of these events, $\kappa_{\mathrm{c}, \mathrm{GF}}$ is at least $20 \%$ lower than $\kappa_{\mathrm{c}, \mathrm{CCN}}$, indicating organics likely played an important role in particle condensational growth. In addition, the chemical composition of submicron non-refractory aerosol (NR-PM ${ }_{1}$; aerodynamic diameters below $1 \mu \mathrm{m}$ ) indicates an ammonium-poor condition over the ENA (color bar in Fig. 5), typical of the remote marine environment (Adams et al., 1999). Therefore, sulfate is not fully neutralized as $\left(\mathrm{NH}_{4}\right)_{2} \mathrm{SO}_{4}$. Note that the bulk $\mathrm{NH}_{4}^{+} / \mathrm{SO}_{4}^{2-}$ molar ratio shown in Fig. 5 is dominated by that of accumulation-mode particles, whereas the $\kappa_{\mathrm{c}, \mathrm{CCN}}$ and $\kappa_{\mathrm{c}, \mathrm{GF}}$ values are derived from growing Aitken-mode particles. Whereas the degrees of neutralization for accumulation and Aitken modes are expected to correlate with each other (e.g., lower neutralization degrees for both accumulation and Aitken modes under more ammonium-poor conditions), it is possible that the neutralization degree may exhibit size dependence under some circumstances. For example, in-

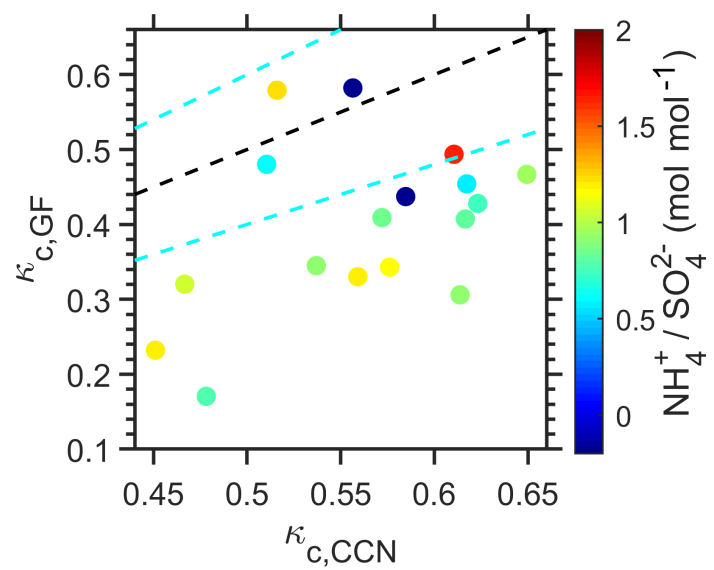

Figure 5. Comparison of $\kappa_{\mathrm{c}, \mathrm{CCN}}$ and $\kappa_{\mathrm{c}, \mathrm{GF}}$ values for the intermediate $\kappa_{\mathrm{c}, \mathrm{CCN}}$ category, colored by the measured molar ratios of $\mathrm{NH}_{4}^{+} / \mathrm{SO}_{4}^{2-}$. The dashed black line is the $1: 1$ line, while the dashed cyan lines represent the $\pm 20 \%$ uncertainties.

cloud formation of $\mathrm{SO}_{4}^{2-}$ influences the neutralization degree of accumulation-mode particles only (Seinfeld and Pandis, 2016), possibly leading to a lower degree of neutralization for the accumulation mode. This could explain a few data points that exhibit a lower degree of neutralization but similar $\kappa_{\mathrm{c}, \mathrm{CCN}}$ and $\kappa_{\mathrm{c}, \mathrm{GF}}$ values. This evidence suggests that the condensed species are a mixture of sulfates and organics during most of the intermediate $\kappa_{\mathrm{c}, \mathrm{CCN}}$ events. These events are not dominated by $\left(\mathrm{NH}_{4}\right)_{2} \mathrm{SO}_{4}$. Based on a $\kappa_{\mathrm{CCN}}$ value of 0.9 for acidic sulfates $\left(\mathrm{H}_{2} \mathrm{SO}_{4}\right.$ and/or $\mathrm{NH}_{4} \mathrm{HSO}_{4}$, Table 1), the average contribution of organics during the intermediate $\kappa_{\mathrm{c}, \mathrm{CCN}}$ events ranges from $42 \%$ to $63 \%$, depending on the $\kappa_{\mathrm{CCN}}$ values of organics assumed $(0.1-0.36$; Table 1$)$. Therefore, organics played an important role during the intermediate $\kappa_{\mathrm{c}, \mathrm{CCN}}$ events and dominated the particle condensational growth for the low $\kappa_{\mathrm{c}, \mathrm{CCN}}$ category. Together, these two categories represent a total of $\sim 80 \%$ of the growth events that occurred throughout the year.

\section{Sources of the condensing organics}

Given the importance of secondary organics to particle condensational growth, the potential sources of the condensing organics are investigated by examining the air mass origins (Sect. S1 in the Supplement). Here we classify the origin of air mass during the growth events into four types: (1) continental air masses from North America or Europe, (2) the Arctic, (3) the subtropics, and (4) the midlatitude Atlantic. Note that an air mass is denoted as continental if it passed over North America or Europe, so the non-continental types represent the air masses that had stayed over oceans or clean continental areas (i.e., Arctic region) for at least $10 \mathrm{~d}$ (Sect. S1). The mixing ratios of $\mathrm{CO}$ and $\mathrm{O}_{3}$ measured at the ENA site exhibit the highest and lower values for the continental and 


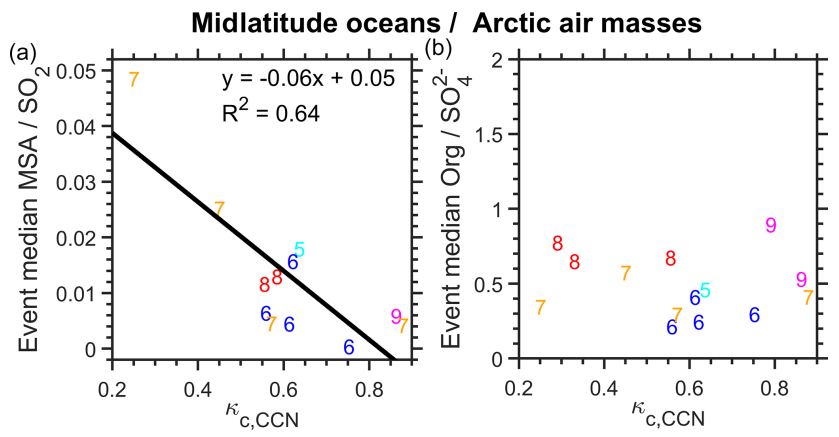

During the other events, air masses were potentially influenced by continental emissions (Fig. S2). For these events, $\kappa_{\mathrm{c}, \mathrm{CCN}}$ is instead positively correlated with the $\mathrm{MSA} / \mathrm{SO}_{2}$ ratio (Fig. 6c), indicating that secondary organics formed from phytoplankton-emitted VOCs likely played a minor role in the observed particle condensational growth. The $\kappa_{\mathrm{c}, \mathrm{CCN}}$ value generally decreases with increasing NR-PM organic/sulfate ratios (Fig. 6d), suggesting that the formation of SOA led to an increased organic fraction for both pre$\mathrm{CCN}$ and accumulation-mode particles. Possible sources of the condensed organics include SOA generated from longrange-transported continental VOCs and VOCs released by the sea-surface microlayer oxidation that are not directly related to phytoplankton emissions.

As continentally emitted VOCs are removed by oxidation during long-range transport, it is expected that in situ SOA production from these VOCs is low and plays a minor role in particle condensational growth over the remote oceans (Kelly et al., 2019; D'Andrea et al., 2013). On the other hand, aromatic compounds were detected in pre-CCN particles in clean air masses at a coastal site (Lawler et al., 2014), indicating the potential contribution of SOA from anthropogenic VOCs with a long lifetime. Oxidation reactions at the airsea interface can produce VOCs, which lead to subsequent SOA formation (Mungall et al., 2017; Brüggemann et al., 2018). This VOC source is present all-year round, even during winter when there is little biological activity in the ocean (Brüggemann et al., 2018). Therefore, the secondary organics produced via this pathway can contribute to the growth of pre-CCN particles during the seasons when there is little biological activity.

midlatitude ocean air masses, respectively (Fig. S3), supporting the effectiveness of the classifications.

Growth events of midlatitude Atlantic or Arctic type were observed exclusively from May to September, a period that coincides with the phytoplankton blooms in the midlatitude Atlantic or Arctic but not the subtropics (Sapiano et al., 2012). For these events, $\kappa_{\mathrm{c}, \mathrm{CCN}}$ is anti-correlated with the $\mathrm{MSA} / \mathrm{SO}_{2}$ ratio (Fig. 6a), which is from MERRA-2 reanalysis data (Sect. 2.3). As fixed yields of $\mathrm{SO}_{2}$ and MSA from DMS oxidation are assumed in MERRA-2 data (Chin et al., 2000; Randles et al., 2017), a lower $\mathrm{MSA} / \mathrm{SO}_{2}$ ratio suggests that other $\mathrm{SO}_{2}$ sources in addition to DMS oxidation contribute to these events. These other sources could include volcanic emissions and combustion products from international shipping (Randles et al., 2017). As MSA is a tracer of biogenically derived SOA in marine environment (Seinfeld and Pandis, 2016), the anti-correlation also indicates that the condensed organics are likely SOA produced from VOCs emitted from ocean biological activities (e.g., phytoplankton blooms). The value of $\kappa_{\mathrm{c}, \mathrm{CCN}}$ is not correlated with the NR-PM 1 organic/sulfate ratio (Fig. 6b), suggesting different sources of the condensed species in pre- $\mathrm{CCN}$ and the accumulation-mode particle composition.

Among the remaining growth events, only four of them are subtropical cases, which occurred outside the bloom periods. 
Supplement. The supplement related to this article is available online at: https://doi.org/10.5194/acp-20-12515-2020-supplement.

Author contributions. JW and GZ designed the study. JW, GZ, CK, JU, and TW carried out the measurements, and GZ and JW conducted the analysis and wrote the manuscript with contributions from all authors.

Competing interests. The authors declare that they have no conflict of interest.

Special issue statement. This article is part of the special issue "Marine aerosols, trace gases, and clouds over the North Atlantic (ACP/AMT inter-journal SI)". It is not associated with a conference.

Acknowledgements. The research was conducted with funding from the Atmospheric System Research (ASR) program (award no. DE-SC0020259), Office of Biological and Environmental Research (OBER) of the United States Department of Energy. We acknowledge additional support by the Atmospheric Radiation Measurement (ARM) Climate Research Facility, a user facility of the United States Department of Energy, Office of Science, sponsored by the Office of Biological and Environmental Research.

Financial support. This research has been supported by the Atmospheric System Research program, US Department of Energy (grant no. DE-SC0020259).

Review statement. This paper was edited by Ryan Sullivan and reviewed by three anonymous referees.

\section{References}

Adams, P. J., Seinfeld, J. H., and Koch, D. M.: Global concentrations of tropospheric sulfate, nitrate, and ammonium aerosol simulated in a general circulation model, J. Geophys. Res.-Atmos., 104, 13791-13823, https://doi.org/10.1029/1999jd900083, 1999.

Andreae, M. O., Ferek, R. J., Bermond, F., Byrd, K. P., Engstrom, R. T., Hardin, S., Houmere, P. D., LeMarrec, F., Raemdonck, H., and Chatfield, R. B.: Dimethyl sulfide in the marine atmosphere, J. Geophys. Res.-Atmos., 90, 12891-12900, https://doi.org/10.1029/JD090iD07p12891, 1985.

ARM: ACE-ENA, Aerosol and Cloud Experiments in the Eastern North Atlantic (ACE-ENA), available at: https://www.arm. gov/research/campaigns/aaf2017ace-ena (last access: 15 October 2020), 2013.

Brüggemann, M., Hayeck, N., and George, C.: Interfacial photochemistry at the ocean surface is a global source of organic vapors and aerosols, Nat. Commun., 9, 2101, https://doi.org/10.1038/s41467-018-04528-7, 2018.

Bzdek, B. R., Lawler, M. J., Horan, A. J., Pennington, M. R., DePalma, J. W., Zhao, J., Smith, J. N., and Johnston, M. V.: Molecular constraints on particle growth during new particle formation, Geophys. Res. Lett., 41, 6045-6054, https://doi.org/10.1002/2014g1060160, 2014.

Carslaw, K., Lee, L., Reddington, C., Pringle, K., Rap, A., Forster, P., Mann, G., Spracklen, D., Woodhouse, M., and Regayre, L.: Large contribution of natural aerosols to uncertainty in indirect forcing, Nature, 503, 67-71, 2013.

Chang, R. Y.-W., Slowik, J. G., Shantz, N. C., Vlasenko, A., Liggio, J., Sjostedt, S. J., Leaitch, W. R., and Abbatt, J. P. D.: The hygroscopicity parameter $(\kappa)$ of ambient organic aerosol at a field site subject to biogenic and anthropogenic influences: relationship to degree of aerosol oxidation, Atmos. Chem. Phys., 10, 5047-5064, https://doi.org/10.5194/acp-10-5047-2010, 2010.

Charlson, R. J., Lovelock, J. E., Andreae, M. O., and Warren, S. G.: Oceanic phytoplankton, atmospheric sulphur, cloud albedo and climate, Nature, 326, 655-661, https://doi.org/10.1038/326655a0, 1987.

Chin, M., Rood, R. B., Lin, S.-J., Müller, J.-F., and Thompson, A. M.: Atmospheric sulfur cycle simulated in the global model GOCART: Model description and global properties, J. Geophys. Res.-Atmos., 105, 24671-24687, https://doi.org/10.1029/2000jd900384, 2000.

D’Andrea, S. D., Häkkinen, S. A. K., Westervelt, D. M., Kuang, C., Levin, E. J. T., Kanawade, V. P., Leaitch, W. R., Spracklen, D. V., Riipinen, I., and Pierce, J. R.: Understanding global secondary organic aerosol amount and size-resolved condensational behavior, Atmos. Chem. Phys., 13, 11519-11534, https://doi.org/10.5194/acp-13-11519-2013, 2013.

Dall'Osto, M., Ceburnis, D., Monahan, C., Worsnop, D. R., Bialek, J., Kulmala, M., Kurtén, T., Ehn, M., Wenger, J., Sodeau, J., Healy, R., and O'Dowd, C.: Nitrogenated and aliphatic organic vapors as possible drivers for marine secondary organic aerosol growth, J. Geophys. Res.-Atmos., 117, D12311, https://doi.org/10.1029/2012jd017522, 2012.

Facchini, M. C., Rinaldi, M., Decesari, S., Carbone, C., Finessi, E., Mircea, M., Fuzzi, S., Ceburnis, D., Flanagan, R., Nilsson, E. D., de Leeuw, G., Martino, M., Woeltjen, J., and O'Dowd, C. D.: Primary submicron marine aerosol dominated by insoluble organic colloids and aggregates, Geophys. Res. Lett., 35, L17814, https://doi.org/10.1029/2008GL034210, 2008.

Frank, G. P., Dusek, U., and Andreae, M. O.: Technical note: A method for measuring size-resolved $\mathrm{CCN}$ in the atmosphere, Atmos. Chem. Phys. Discuss., 6, 4879-4895, https://doi.org/10.5194/acpd-6-4879-2006, 2006.

Gelaro, R., McCarty, W., Suárez, M. J., Todling, R., Molod, A., Takacs, L., Randles, C. A., Darmenov, A., Bosilovich, M. G., Reichle, R., Wargan, K., Coy, L., Cullather, R., Draper, C., Akella, S., Buchard, V., Conaty, A., Silva, A. M. d., Gu, W., Kim, G.K., Koster, R., Lucchesi, R., Merkova, D., Nielsen, J. E., Partyka, G., Pawson, S., Putman, W., Rienecker, M., Schubert, S. D., Sienkiewicz, M., and Zhao, B.: The Modern-Era Retrospective Analysis for Research and Applications, Version 2 (MERRA2), J. Climate, 30, 5419-5454, https://doi.org/10.1175/jcli-d-160758.1, 2017. 
Hodshire, A. L., Campuzano-Jost, P., Kodros, J. K., Croft, B., Nault, B. A., Schroder, J. C., Jimenez, J. L., and Pierce, J. R.: The potential role of methanesulfonic acid (MSA) in aerosol formation and growth and the associated radiative forcings, Atmos. Chem. Phys., 19, 3137-3160, https://doi.org/10.5194/acp19-3137-2019, 2019.

Hoppel, W. A., Fitzgerald, J. W., Frick, G. M., Larson, R. E., and Mack, E. J.: Aerosol size distributions and optical properties found in the marine boundary layer over the Atlantic Ocean, J. Geophys. Res.-Atmos., 95, 3659-3686, https://doi.org/10.1029/JD095iD04p03659, 1990.

Hu, Q.-H., Xie, Z.-Q., Wang, X.-M., Kang, H., He, Q.-F., and Zhang, P.: Secondary organic aerosols over oceans via oxidation of isoprene and monoterpenes from Arctic to Antarctic, Sci. RepUk, 3, 2280, https://doi.org/10.1038/srep02280, 2013.

Johnson, G. R., Ristovski, Z., and Morawska, L.: Method for measuring the hygroscopic behaviour of lower volatility fractions in an internally mixed aerosol, J. Aerosol Sci., 35, 443-455, https://doi.org/10.1016/j.jaerosci.2003.10.008, 2004.

Karl, M., Gross, A., Pirjola, L., and Leck, C.: A new flexible multicomponent model for the study of aerosol dynamics in the marine boundary layer, Tellus B, 63, 1001-1025, https://doi.org/10.1111/j.1600-0889.2011.00562.x, 2011.

Kelly, J. M., Doherty, R. M., O’Connor, F. M., Mann, G. W., Coe, H., and Liu, D.: The roles of volatile organic compound deposition and oxidation mechanisms in determining secondary organic aerosol production: a global perspective using the UKCA chemistry-climate model (vn8.4), Geosci. Model Dev., 12, 2539-2569, https://doi.org/10.5194/gmd-12-2539-2019, 2019.

Kerminen, V.-M. and Wexler, A. S.: Growth behavior of the marine submicron boundary layer aerosol, J. Geophys. Res.-Atmos., 102, 18813-18825, https://doi.org/10.1029/97jd01260, 1997.

Kim, M. J., Novak, G. A., Zoerb, M. C., Yang, M., Blomquist, B. W., Huebert, B. J., Cappa, C. D., and Bertram, T. H.: Air-Sea exchange of biogenic volatile organic compounds and the impact on aerosol particle size distributions, Geophys. Res. Lett., 44, 3887-3896, https://doi.org/10.1002/2017g1072975, 2017.

Kulmala, M., Pirjola, L., and Mäkelä, J. M.: Stable sulphate clusters as a source of new atmospheric particles, Nature, 404, 66-69, https://doi.org/10.1038/35003550, 2000.

Lance, S., Raatikainen, T., Onasch, T. B., Worsnop, D. R., Yu, X.Y., Alexander, M. L., Stolzenburg, M. R., McMurry, P. H., Smith, J. N., and Nenes, A.: Aerosol mixing state, hygroscopic growth and cloud activation efficiency during MIRAGE 2006, Atmos. Chem. Phys., 13, 5049-5062, https://doi.org/10.5194/acp-135049-2013, 2013.

Lawler, M. J., Whitehead, J., O'Dowd, C., Monahan, C., McFiggans, G., and Smith, J. N.: Composition of 15-85 nm particles in marine air, Atmos. Chem. Phys., 14, 11557-11569, https://doi.org/10.5194/acp-14-11557-2014, 2014.

Massoli, P., Lambe, A. T., Ahern, A. T., Williams, L. R., Ehn, M., Mikkilä, J., Canagaratna, M. R., Brune, W. H., Onasch, T. B., Jayne, J. T., Petäjä, T., Kulmala, M., Laaksonen, A., Kolb, C. E., Davidovits, P., and Worsnop, D. R.: Relationship between aerosol oxidation level and hygroscopic properties of laboratory generated secondary organic aerosol (SOA) particles, Geophys. Res. Lett., 37, L24801, https://doi.org/10.1029/2010g1045258, 2010.
Mather, J. H. and Voyles, J. W.: The Arm Climate Research Facility: A Review of Structure and Capabilities, B. Am. Meteorol. Soc., 94, 377-392, https://doi.org/10.1175/bams-d-11-00218.1, 2013.

Mei, F., Hayes, P. L., Ortega, A., Taylor, J. W., Allan, J. D., Gilman, J., Kuster, W., de Gouw, J., Jimenez, J. L., and Wang, J.: Droplet activation properties of organic aerosols observed at an urban site during CalNex-LA, J. Geophys. Res.-Atmos., 118, 2903-2917, https://doi.org/10.1002/jgrd.50285, 2013a.

Mei, F., Setyan, A., Zhang, Q., and Wang, J.: CCN activity of organic aerosols observed downwind of urban emissions during CARES, Atmos. Chem. Phys., 13, 12155-12169, https://doi.org/10.5194/acp-13-12155-2013, 2013 b.

Modini, R. L., Ristovski, Z. D., Johnson, G. R., He, C., Surawski, N., Morawska, L., Suni, T., and Kulmala, M.: New particle formation and growth at a remote, sub-tropical coastal location, Atmos. Chem. Phys., 9, 7607-7621, https://doi.org/10.5194/acp-97607-2009, 2009.

Moore, R. H., Nenes, A., and Medina, J.: Scanning Mobility CCN Analysis - A Method for Fast Measurements of Size-Resolved CCN Distributions and Activation Kinetics, Aerosol Sci. Technol., 44, 861-871, https://doi.org/10.1080/02786826.2010.498715, 2010.

Mungall, E. L., Abbatt, J. P. D., Wentzell, J. J. B., Lee, A. K. Y., Thomas, J. L., Blais, M., Gosselin, M., Miller, L. A., Papakyriakou, T., Willis, M. D., and Liggio, J.: Microlayer source of oxygenated volatile organic compounds in the summertime marine Arctic boundary layer, P. Natl. Acad. Sci. USA, 114, 6203-6208, https://doi.org/10.1073/pnas.1620571114, 2017.

O'Dowd, C. D., Lowe, J. A., and Smith, M. H.: Observations and modelling of aerosol growth in marine stratocumulus - case study, Atmos. Environ., 33, 3053-3062, https://doi.org/10.1016/S1352-2310(98)00213-1, 1999.

Ovadnevaite, J., Ceburnis, D., Martucci, G., Bialek, J., Monahan, C., Rinaldi, M., Facchini, M. C., Berresheim, H., Worsnop, D. R., and O'Dowd, C.: Primary marine organic aerosol: A dichotomy of low hygroscopicity and high CCN activity, Geophys. Res. Lett., 38, L21806, https://doi.org/10.1029/2011GL048869, 2011.

Ovadnevaite, J., Zuend, A., Laaksonen, A., Sanchez, K. J., Roberts, G., Ceburnis, D., Decesari, S., Rinaldi, M., Hodas, N., Facchini, M. C., Seinfeld, J. H., and O' Dowd, C.: Surface tension prevails over solute effect in organic-influenced cloud droplet activation, Nature, 546, 637-641, https://doi.org/10.1038/nature22806, 2017.

Pajunoja, A., Lambe, A. T., Hakala, J., Rastak, N., Cummings, M. J., Brogan, J. F., Hao, L., Paramonov, M., Hong, J., Prisle, N. L., Malila, J., Romakkaniemi, S., Lehtinen, K. E. J., Laaksonen, A., Kulmala, M., Massoli, P., Onasch, T. B., Donahue, N. M., Riipinen, I., Davidovits, P., Worsnop, D. R., Petäjä, T., and Virtanen, A.: Adsorptive uptake of water by semisolid secondary organic aerosols, Geophys. Res. Lett., 42, 3063-3068, https://doi.org/10.1002/2015gl063142, 2015.

Pandis, S. N., Russell, L. M., and Seinfeld, J. H.: The relationship between DMS flux and CCN concentration in remote marine regions, J. Geophys. Res.-Atmos., 99, 16945-16957, https://doi.org/10.1029/94JD01119, 1994.

Petters, M. D. and Kreidenweis, S. M.: A single parameter representation of hygroscopic growth and cloud condensation nucleus activity, Atmos. Chem. Phys., 7, 1961-1971, https://doi.org/10.5194/acp-7-1961-2007, 2007. 
Petters, M. D., Prenni, A. J., Kreidenweis, S. M., and DeMott, P. J.: On Measuring the Critical Diameter of Cloud Condensation Nuclei Using Mobility Selected Aerosol, Aerosol Sci. Technol., 41, 907-913, https://doi.org/10.1080/02786820701557214, 2007.

Petters, M. D., Wex, H., Carrico, C. M., Hallbauer, E., Massling, A., McMeeking, G. R., Poulain, L., Wu, Z., Kreidenweis, S. M., and Stratmann, F.: Towards closing the gap between hygroscopic growth and activation for secondary organic aerosol - Part 2: Theoretical approaches, Atmos. Chem. Phys., 9, 3999-4009, https://doi.org/10.5194/acp-9-3999-2009, 2009.

Pierce, J. R. and Adams, P. J.: Global evaluation of $\mathrm{CCN}$ formation by direct emission of sea salt and growth of ultrafine sea salt, J. Geophys. Res.-Atmos., 111, D06203, https://doi.org/10.1029/2005jd006186, 2006.

Quinn, P. K., Coffman, D. J., Johnson, J. E., Upchurch, L. M., and Bates, T. S.: Small fraction of marine cloud condensation nuclei made up of sea spray aerosol, Nat. Geosci., 10, 674-679, 2017.

Raes, F. and Van Dingenen, R.: Simulations of condensation and cloud condensation nuclei from biogenic $\mathrm{SO}_{2}$ in the remote marine boundary layer, J. Geophys. Res.-Atmos., 97, 12901-12912, https://doi.org/10.1029/92jd00961, 1992.

Randles, C., Da Silva, A., Buchard, V., Colarco, P., Darmenov, A., Govindaraju, R., Smirnov, A., Holben, B., Ferrare, R., and Hair, J.: The MERRA-2 aerosol reanalysis, 1980 onward. Part I: System description and data assimilation evaluation, J. Climate, 30, 6823-6850, 2017.

Rastak, N., Pajunoja, A., Acosta Navarro, J. C., Ma, J., Song, M., Partridge, D. G., Kirkevåg, A., Leong, Y., Hu, W. W., Taylor, N. F., Lambe, A., Cerully, K., Bougiatioti, A., Liu, P., Krejci, R., Petäjä, T., Percival, C., Davidovits, P., Worsnop, D. R., Ekman, A. M. L., Nenes, A., Martin, S., Jimenez, J. L., Collins, D. R., Topping, D. O., Bertram, A. K., Zuend, A., Virtanen, A., and Riipinen, I.: Microphysical explanation of the RH-dependent water affinity of biogenic organic aerosol and its importance for climate, Geophys. Res. Lett., 44, 5167-5177, https://doi.org/10.1002/2017GL073056, 2017.

Rose, D., Gunthe, S. S., Mikhailov, E., Frank, G. P., Dusek, U., Andreae, M. O., and Pöschl, U.: Calibration and measurement uncertainties of a continuous-flow cloud condensation nuclei counter (DMT-CCNC): CCN activation of ammonium sulfate and sodium chloride aerosol particles in theory and experiment, Atmos. Chem. Phys., 8, 1153-1179, https://doi.org/10.5194/acp8-1153-2008, 2008.

Rosenfeld, D., Zhu, Y., Wang, M., Zheng, Y., Goren, T., and Yu, S.: Aerosol-driven droplet concentrations dominate coverage and water of oceanic low-level clouds, Science, 363, eaav0566, https://doi.org/10.1126/science.aav0566, 2019.

Sanchez, K. J., Chen, C.-L., Russell, L. M., Betha, R., Liu, J., Price, D. J., Massoli, P., Ziemba, L. D., Crosbie, E. C., Moore, R. H., Müller, M., Schiller, S. A., Wisthaler, A., Lee, A. K. Y., Quinn, P. K., Bates, T. S., Porter, J., Bell, T. G., Saltzman, E. S., Vaillancourt, R. D., and Behrenfeld, M. J.: Substantial Seasonal Contribution of Observed Biogenic Sulfate Particles to Cloud Condensation Nuclei, Sci. Rep-Uk, 8, 3235, https://doi.org/10.1038/s41598-018-21590-9, 2018.

Sapiano, M. R. P., Brown, C. W., Schollaert Uz, S., and Vargas, M.: Establishing a global climatology of marine phytoplankton phenological characteristics, J. Geophys. Res.-Oceans, 117, C08026, https://doi.org/10.1029/2012jc007958, 2012.
Schmale, J., Henning, S., Decesari, S., Henzing, B., Keskinen, H., Sellegri, K., Ovadnevaite, J., Pöhlker, M. L., Brito, J., Bougiatioti, A., Kristensson, A., Kalivitis, N., Stavroulas, I., Carbone, S., Jefferson, A., Park, M., Schlag, P., Iwamoto, Y., Aalto, P., Äijälä, M., Bukowiecki, N., Ehn, M., Frank, G., Fröhlich, R., Frumau, A., Herrmann, E., Herrmann, H., Holzinger, R., Kos, G., Kulmala, M., Mihalopoulos, N., Nenes, A., O’Dowd, C., Petäjä, T., Picard, D., Pöhlker, C., Pöschl, U., Poulain, L., Prévôt, A. S. H., Swietlicki, E., Andreae, M. O., Artaxo, P., Wiedensohler, A., Ogren, J., Matsuki, A., Yum, S. S., Stratmann, F., Baltensperger, U., and Gysel, M.: Long-term cloud condensation nuclei number concentration, particle number size distribution and chemical composition measurements at regionally representative observatories, Atmos. Chem. Phys., 18, 2853-2881, https://doi.org/10.5194/acp-18-2853-2018, 2018.

Seinfeld, J. H. and Pandis, S. N.: Atmospheric chemistry and physics: from air pollution to climate change, John Wiley \& Sons, 2016.

Swan, H. B., Crough, R. W., Vaattovaara, P., Jones, G. B., Deschaseaux, E. S. M., Eyre, B. D., Miljevic, B., and Ristovski, Z. D.: Dimethyl sulfide and other biogenic volatile organic compound emissions from branching coral and reef seawater: potential sources of secondary aerosol over the Great Barrier Reef, J. Atmos. Chem., 73, 303-328, https://doi.org/10.1007/s10874016-9327-7, 2016.

Tang, M., Guo, L., Bai, Y., Huang, R.-J., Wu, Z., Wang, Z., Zhang, G., Ding, X., Hu, M., and Wang, X.: Impacts of methanesulfonate on the cloud condensation nucleation activity of sea salt aerosol, Atmos. Environ., 201, 13-17, https://doi.org/10.1016/j.atmosenv.2018.12.034, 2019.

Thalman, R., de Sá, S. S., Palm, B. B., Barbosa, H. M. J., Pöhlker, M. L., Alexander, M. L., Brito, J., Carbone, S., Castillo, P., Day, D. A., Kuang, C., Manzi, A., Ng, N. L., Sedlacek III, A. J., Souza, R., Springston, S., Watson, T., Pöhlker, C., Pöschl, U., Andreae, M. O., Artaxo, P., Jimenez, J. L., Martin, S. T., and Wang, J.: CCN activity and organic hygroscopicity of aerosols downwind of an urban region in central Amazonia: seasonal and diel variations and impact of anthropogenic emissions, Atmos. Chem. Phys., 17, 11779-11801, https://doi.org/10.5194/acp-1711779-2017, 2017.

Uin, J.: 3002 Humidified Tandem Differential Mobility Analyzer Instrument Handbook, DOE Office of Science Atmospheric Radiation Measurement (ARM) Program, 2016.

Vaattovaara, P., Huttunen, P. E., Yoon, Y. J., Joutsensaari, J., Lehtinen, K. E. J., O'Dowd, C. D., and Laaksonen, A.: The composition of nucleation and Aitken modes particles during coastal nucleation events: evidence for marine secondary organic contribution, Atmos. Chem. Phys., 6, 4601-4616, https://doi.org/10.5194/acp-6-4601-2006, 2006.

Wang, J., Dong, X., and Wood, R.: Aerosol and Cloud Experiments in Eastern North Atlantic (ACE-ENA) Science Plan, DOE Office of Science Atmospheric Radiation Measurement (ARM) Program, 2016.

Watson, T. B.: Aerosol chemical speciation monitor (ACSM) instrument handbook, DOE Office of Science Atmospheric Radiation Measurement (ARM) Program, 2017.

Wex, H., Petters, M. D., Carrico, C. M., Hallbauer, E., Massling, A., McMeeking, G. R., Poulain, L., Wu, Z., Kreidenweis, S. M., and Stratmann, F.: Towards closing the gap between hygroscopic 
growth and activation for secondary organic aerosol: Part $1-\mathrm{Ev}$ idence from measurements, Atmos. Chem. Phys., 9, 3987-3997, https://doi.org/10.5194/acp-9-3987-2009, 2009.

Willis, M. D., Burkart, J., Thomas, J. L., Köllner, F., Schneider, J., Bozem, H., Hoor, P. M., Aliabadi, A. A., Schulz, H., Herber, A. B., Leaitch, W. R., and Abbatt, J. P. D.: Growth of nucleation mode particles in the summertime Arctic: a case study, Atmos. Chem. Phys., 16, 7663-7679, https://doi.org/10.5194/acp16-7663-2016, 2016.

Willis, M. D., Köllner, F., Burkart, J., Bozem, H., Thomas, J. L., Schneider, J., Aliabadi, A. A., Hoor, P. M., Schulz, H., Herber, A. B., Leaitch, W. R., and Abbatt, J. P. D.: Evidence for marine biogenic influence on summertime Arctic aerosol, Geophys. Res. Lett., 44, 6460-6470, https://doi.org/10.1002/2017gl073359, 2017.

Wood, R.: Stratocumulus Clouds, Mon. Weather Rev., 140, 23732423, https://doi.org/10.1175/mwr-d-11-00121.1, 2012.

Wood, R., Wyant, M., Bretherton, C. S., Rémillard, J., Kollias, P., Fletcher, J., Stemmler, J., Szoeke, S. d., Yuter, S., Miller, M., Mechem, D., Tselioudis, G., Chiu, J. C., Mann, J. A. L., O'Connor, E. J., Hogan, R. J., Dong, X., Miller, M., Ghate, V., Jefferson, A., Min, Q., Minnis, P., Palikonda, R., Albrecht, B., Luke, E., Hannay, C., and Lin, Y.: Clouds, Aerosols, and Precipitation in the Marine Boundary Layer: An Arm Mobile Facility Deployment, B. Am. Meteorol. Soc., 96, 419-440, https://doi.org/10.1175/bams-d-13-00180.1, 2015.
Wurl, O., Wurl, E., Miller, L., Johnson, K., and Vagle, S.: Formation and global distribution of sea-surface microlayers, Biogeosciences, 8, 121-135, https://doi.org/10.5194/bg-8-1212011, 2011.

Yu, F. and Luo, G.: Simulation of particle size distribution with a global aerosol model: contribution of nucleation to aerosol and CCN number concentrations, Atmos. Chem. Phys., 9, 76917710, https://doi.org/10.5194/acp-9-7691-2009, 2009.

Zheng, G., Wang, Y., Aiken, A. C., Gallo, F., Jensen, M. P., Kollias, P., Kuang, C., Luke, E., Springston, S., Uin, J., Wood, R., and Wang, J.: Marine boundary layer aerosol in the eastern North Atlantic: seasonal variations and key controlling processes, Atmos. Chem. Phys., 18, 17615-17635, https://doi.org/10.5194/acp-1817615-2018, 2018.

Zheng, G., Sedlacek, A. J., Aiken, A. C., Feng, Y., Watson, T. B., Raveh-Rubin, S., Uin, J., Lewis, E. R., and Wang, J.: Long-range transported North American wildfire aerosols observed in marine boundary layer of eastern North Atlantic, Environ. Int., 139, 105680, https://doi.org/10.1016/j.envint.2020.105680, 2020. 